\title{
Effect of Different Tillage Methods and Plant Spacing on Growth and Herbage Yield of Lagos Spinach (Celosia argentea L.)
}

\section{Modupeola TO $^{1 *}$, Dixon HG ${ }^{1}$ and Adewumi AG ${ }^{2}$}

${ }^{1}$ National Institute Horticultural Research, Oyo State, Nigeria

${ }^{2}$ Faculty of Agricultural Sciences, Department of Agronomy, Ladoke Akintola University of Technology, Oyo State, Nigeria

\begin{abstract}
The field experiment was carried out at the National Horticultural Research Institute (NIHORT) Idi-Ishin Jericho, Ibadan to determine the growth and herbage yield of Lagos spinach (Celosia argentea L.) as affected by different tillage methods and plant spacing. The experiment was a Randomized Complete Block Design (RCBD) involving twelve treatments, replicated three times. The plot size used was $2 \mathrm{~m} \times 3 \mathrm{~m}$ with $1 \mathrm{~m}$ path ways between plots and $1 \mathrm{~m}$ between replicates. The treatments were different plant spacing $(15 \mathrm{~cm} \times 30 \mathrm{~cm}, 30 \mathrm{~cm} \times 30 \mathrm{~cm}, 45 \mathrm{~cm} \times 30$ $\mathrm{cm}$ and $60 \mathrm{~cm} \times 30 \mathrm{~cm}$ ) and tillage methods (raise bed, ridges and flatbed). The result showed that the plants from raised bed at spacing of $30 \mathrm{~cm} \times 30 \mathrm{~cm}$ (111,111 plants per ha) gave the highest response in terms of average growth parameters that were considered at 7 WAP and the yield value after harvesting at $8^{\text {th }}$ week. The spacing of $30 \mathrm{~cm} \times$ $30 \mathrm{~cm}$ from raised bed gave the highest fresh herbage yield of the Celosia planted.
\end{abstract}

Keywords: Plant spacing; Planting methods; Growth; Herbage yield; Celosia

\section{Introduction}

Celosia argentea commonly known as pumped cockscomb is an edible species of the genus Celosia of the Amaranthaceae family. Its centre of origin is India. Celosia is primarily used as a leafy vegetable [1]. It is one of the important home garden vegetable in South West Nigeria [2]. The diversity of Celosia argentea in tropical Africa point to its origin is this region [3]. Celosia is a wide spread plant throughout this region. It is also an important vegetable in Southern Benin, Togo, Ghana and Cameroon [4]. Outside Africa, it occurs in tropical and subtropical Asia and America [5]. These forms of Celosia were widely grown as ornamentals in the temperate regions [6]. Celosia grows well in the low land humid forest zone within day temperatures of $30-35^{\circ} \mathrm{C}$ and night temperatures of $23-28^{\circ} \mathrm{C}$ at an altitude up to $1700 \mathrm{~m}$. Growth is greatly retarded by temperatures below $20^{\circ} \mathrm{C}$. Consequently, it does not grow well in the savanna region of West Africa during the Harmattan period. Celosia performs well under partial shade, especially in dry conditions. It is often considered as a variety or a type of Amaranthus, since the growth habit, the cultivation and the management practices used is very similar. However, in contrast to Amaranthus, Celosia follows C3-cycle photosynthetic pathway, $60 \%$ of full sunlight is therefore adequate for optimal growth, which makes Celosia especially suitable for production in shady home gardens. Celosia grows well on a well-drained sandy loam soil allows optimum growth, but Celosia also grows well on marshy soils. In Nigeria and Republic of Benin, it is frequently produced during the dry season using irrigation the "FADAMA" cropping system on hydromorphic soils of river banks and seasonal flooded areas. Celosia tolerates moderately saline soils of $25-30 \mathrm{~mm} \mathrm{NaCl}$. It is also moderately resistant to drought and performs well under low water supply of the dry season, but severe drought promotes early flowering. The rainfall requirement ranges between $500 \mathrm{~mm}-1000 \mathrm{~mm}$.

However, among the major production constraints are cropping pattern and tillage method. Kusnarta et al. [7] noted that the system of soil management controls root distribution and soil properties such as porosity, compaction, water content and concentration of organic matter. Several other researchers have well noted that seedbed types have effects on seedling emergence, growth and productivity of crops through influence on soil physical, chemical and biological properties
[8-12]. Thus, management practices that can easily be adopted by farmers to conserve soil moisture and nutrients will be viable options to adopt on a sustainable basis. Tillage methods that are already known to farmers if proven to be useful will provide a better option for use under farmer's conditions. Despite the huge advantages of various uses of Celosia, its production has some constraints. The major constraints to Celosia production are; pests, diseases, weed, cropping pattern, soil fertility and tillage methods. Therefore, extensive investigation is needed to understand the compatibility of different plant spacing and tillage methods on Celosia. Therefore, the objective of this study was to determine the effect of population density and different tillage methods on the growth and herbage yield of Celosia argentea.

\section{Materials and Methods}

The experiment was conducted at National Horticultural Research Institute (NIHORT) Idi-shin Jericho, Ibadan. NIHORT is located at the Western zone of the city, geographically located in the rain forest belt of Nigeria. The experimental design used was a randomized complete block design (RCBD) with 3 replicates, a plot size of $2 \mathrm{~m} \times 3 \mathrm{~m}\left(6 \mathrm{~m}^{2}\right)$ with $1 \mathrm{~m}$ path ways between plots and $1 \mathrm{~m}$ between replicates. The treatment considered were different tillage methods (raise bed, ridges and flatbed) and plant spacing $(15 \mathrm{~cm} \times 30 \mathrm{~cm}, 30 \mathrm{~cm} \times 30 \mathrm{~cm}, 45 \mathrm{~cm}$ $\times 30 \mathrm{~cm}$ and $60 \mathrm{~cm} \times 30 \mathrm{~cm})$. Data collection was done at 3,5 and 7 weeks after planting. Five plants sample were randomly selected and tagged for data collection. Data was collected on plant height, number of leaves, stem girth and herbage yield. Data collected were subjected to Analysis of Variance (ANOVA) and significant means were separated using Least Significant Difference at 5\% level of probability (LSD).

"Corresponding author: Modupeola TO, National Institute Horticultural Research, Oyo State, Nigeria Tel: +49-15-758812342; E-mail: atopson@yahoo.com

Received July 09, 2018; Accepted July 18, 2018; Published July 25, 2018

Citation: Modupeola TO, Dixon HG, Adewumi AG (2018) Effect of Different Tillage Methods and Plant Spacing on Growth and Herbage Yield of Lagos Spinach (Celosia argentea L.). J Pet Environ Biotechnol 9: 373. doi: 10.4172/21577463.1000373

Copyright: ( 2018 Modupeola TO, et al. This is an open-access article distributed under the terms of the Creative Commons Attribution License, which permits unrestricted use, distribution, and reproduction in any medium, provided the original author and source are credited. 


\section{Results and Discussion}

The result obtained from Table 1 , indicate that the soil have heavy metals such as $\mathrm{Fe}^{2+}(11.0 \mathrm{mg} / \mathrm{kg}), \mathrm{Cu}^{2+}(3.20 \mathrm{mg} / \mathrm{kg})$ and $\mathrm{Zn}^{2+}$ $(2.11 \mathrm{mg} / \mathrm{kg})$ respectively. However, comparing the result obtained with World Health Organization (WHO) and Food and Agricultural Organization (FAO) standards (safe limits of 40 and 60 for $\mathrm{Cu}^{2+}$ and $\mathrm{Zn}^{2+}$ respectively). This corroborate the findings of Dixon et al., [13] on evaluation of persistence organic pollutants in vegetables around Ogun River; hence, the amount of heavy metals in the soil under cultivation are still of acceptable quality.

The plant height of Celosia plant increased gradually at the plant aged (Table 2). Plant spacing had a significant $(\mathrm{p}<0.05)$ effect on the plant height at 3 and 7 WAP. The tallest plant $(53.94 \mathrm{~cm})$ was observed at $30 \mathrm{~cm} \times 30 \mathrm{~cm}$ while the shortest plant was recorded at $15 \mathrm{~cm} \times 30 \mathrm{~cm}$ at 7 WAP. Effect of tillage method had significant $(\mathrm{p}<0.05)$ influence on plant height at 3 and 7 WAP. The tallest plant of $48.94 \mathrm{~cm}$ was recorded at the raised bed while the shortest plant $(36.44 \mathrm{~cm})$ was observed at the ridge. The plant spacing and tillage method significantly $(\mathrm{p}<0.05)$ influenced the height of Celosia plant at 3 and 7 WAP (Table 3).

The plant grown in combined treatment of $30 \times 30 \mathrm{~cm}$ spacing with raised bed gave the tallest plant height of $94.25 \mathrm{~cm}$ while the shortest plant of $27.75 \mathrm{~cm}$ was recorded from the combined treatment of $15 \times 30$ $\mathrm{cm}$ with ridge. The stem diameter of Celosia increased gradually as the plant age increases. Spacing had a significant effect $(\mathrm{p}<0.05)$ on the stem diameter at 7 WAP. Stem diameter in $30 \times 30 \mathrm{~cm}$ produced the thickest

\begin{tabular}{|c|c|}
\hline Properties & Value \\
\hline $\mathrm{pH}\left(\mathrm{H}_{2} \mathrm{O}\right)$ & 5.9 \\
\hline Organic $\mathrm{matter}(\mathrm{g} / \mathrm{kg})$ & 4.41 \\
\hline Total $\mathrm{N}(\mathrm{g} / \mathrm{kg})$ & 9.4 \\
\hline Available $\mathrm{P}(\mathrm{mg} / \mathrm{kg})$ & 0.53 \\
\hline $\mathrm{Fe}(\mathrm{mg} / \mathrm{kg})$ & 11 \\
\hline $\mathrm{Cu}(\mathrm{mg} / \mathrm{kg})$ & 3.2 \\
\hline $\mathrm{Zn}(\mathrm{mg} / \mathrm{kg})$ & 2.11 \\
\hline Exchangeable $\mathrm{K}(\mathrm{c} \mathrm{mol} / \mathrm{kg})$ & 0.34 \\
\hline Exchangeable $\mathrm{Na}(\mathrm{c} \mathrm{mol} / \mathrm{kg})$ & 0.26 \\
\hline Exchangeable $\mathrm{Ca}(\mathrm{c} \mathrm{mol} / \mathrm{kg})$ & 3.11 \\
\hline Exchangeable $\mathrm{Mg}(\mathrm{c} \mathrm{mol} / \mathrm{kg})$ & 0.58 \\
\hline Exchangeable acidity $(\mathrm{c} \mathrm{mol} / \mathrm{kg})$ & 0.28 \\
\hline Sand $(\mathrm{g} / \mathrm{kg})$ & 878 \\
\hline Silt $(\mathrm{g} / \mathrm{kg})$ & 110 \\
\hline Clay $(\mathrm{g} / \mathrm{kg})$ & 12 \\
\hline Textural class & Sandy loam \\
\hline
\end{tabular}

Table 1: Pre-cropping physical and chemical properties of the soil in the experimental site.

\begin{tabular}{|c|c|c|c|}
\hline Treatments & 3WAP (cm) & 5WAP (cm) & 7WAP (cm) \\
\hline \multicolumn{4}{|c|}{ Planting method } \\
\hline Flat & 17.49 & 23.34 & 40.65 \\
\hline Raise bed & 20.67 & 27.12 & 48.94 \\
\hline Ridge & 19.26 & 26.01 & 36.44 \\
\hline L.S.D & 0.01 & NS & 0.74 \\
\hline \multicolumn{3}{|c|}{ Spacing } \\
\hline $30 \mathrm{~cm} \times 30 \mathrm{~cm}$ & 18.49 & 24.89 & 32.75 \\
\hline $45 \mathrm{~cm} \times 30 \mathrm{~cm}$ & 16.61 & 25.39 & 53.94 \\
\hline $60 \mathrm{~cm} \times 30 \mathrm{~cm}$ & 22.71 & 27.36 & 46.5 \\
\hline L.S.D. & 18.73 & 24.34 & 34.83 \\
\hline
\end{tabular}

Table 2: Main effect of plant spacing and planting methods on plant height $(\mathrm{cm})$ of Celosia argentea. stem of $4.17 \mathrm{~cm}$ while the stem diameter in $15 \times 30 \mathrm{~cm}$ spacing gave the least value of $3.52 \mathrm{~cm}$ at 7 WAP. Tillage method had a significant effect $(\mathrm{p}<0.05)$ on the stem diameter at all sampling period. The thickest stem of $4.45 \mathrm{~cm}$ was recorded at raised bed while the thinnest stem $(3.49$ $\mathrm{cm}$ ) was observed at flat bed. Plant spacing and tillage method had a significant $(\mathrm{p}<0.05)$ effect on the stem diameter at all sampling period (Tables 4 and 5).

The highest value $(5.70 \mathrm{~cm})$ of the stem diameter was observed at $30 \times 30 \mathrm{~cm}$ spacing in the raised bed while the lowest value of 3.08 $\mathrm{cm}$ was recorded at $30 \times 30 \mathrm{~cm}$ spacing in the flatbed. The number of leaves of Celosia plant increased gradually with the increase in plant age. The plant spaced at $45 \times 30 \mathrm{~cm}$ gave the highest number of leaves (31.42) while plant spaced at $60 \times 30 \mathrm{~cm}$ gave the lowest value of 27.95 . The planting methods had a significant effect on number of leaves at 3 WAP while at 5 and 7 WAP had no significant effect on the leaves. The highest number of leaves (31.09) was recorded at the ridge while the plant at the flat bed produced the lowest number of leaves of 27.62. The combined effect of plant spacing and tillage method improved the number of leaves at $45 \times 30 \mathrm{~cm}$ spacing and the ridge (40.48) while at $30 \times 30 \mathrm{~cm}$ spacing with flatbed had the lowest number of leaves. Increase in vegetative growth at $30 \times 30 \mathrm{~cm}$ spacing was primarily due to the availability of optimum micro nutrients, good and well optimized climatic condition (Tables 6 and 7).

The highest plant height and stem size obtained at $30 \times 30 \mathrm{~cm}$ spacing may be due to competition existing among plants for light,

\begin{tabular}{|c|c|c|c|c|}
\hline $\begin{array}{c}\text { Planting } \\
\text { Method }\end{array}$ & Spacing (cm) & 3WAP (cm) & 5WAP (cm) & 7WP (cm) \\
\hline \multirow{4}{*}{ Flat } & $15 \mathrm{~cm} \times 30 \mathrm{~cm}$ & 22.1 & 26.7 & 35.75 \\
\cline { 2 - 5 } & $30 \mathrm{~cm} \times 30 \mathrm{~cm}$ & 11.67 & 17.53 & 34.33 \\
\cline { 2 - 5 } & $45 \mathrm{~cm} \times 30 \mathrm{~cm}$ & 24.17 & 28.33 & 58.75 \\
\cline { 2 - 5 } & $60 \mathrm{~cm} \times 30 \mathrm{~cm}$ & 12 & 20.8 & 33.75 \\
\hline \multirow{4}{*}{ Raise bed } & $15 \mathrm{~cm} \times 30 \mathrm{~cm}$ & 20.93 & 27.13 & 34.75 \\
\cline { 2 - 5 } & $30 \mathrm{~cm} \times 30 \mathrm{~cm}$ & 21.78 & 36.9 & 94.25 \\
\cline { 2 - 5 } & $45 \mathrm{~cm} \times 30 \mathrm{~cm}$ & 20.83 & 21.07 & 32.75 \\
\cline { 2 - 5 } & $60 \mathrm{~cm} \times 30 \mathrm{~cm}$ & 19.12 & 23.4 & 34 \\
\hline \multirow{4}{*}{ Ridge } & $15 \mathrm{~cm} \times 30 \mathrm{~cm}$ & 12.45 & 20.83 & 27.75 \\
\cline { 2 - 5 } & $30 \mathrm{~cm} \times 30 \mathrm{~cm}$ & 16.37 & 21.73 & 33.25 \\
\cline { 2 - 5 } & $45 \mathrm{~cm} \times 30 \mathrm{~cm}$ & 23.13 & 32.67 & 48 \\
\cline { 2 - 5 } & $60 \mathrm{~cm} \times 30 \mathrm{~cm}$ & 25.07 & 28.88 & 36.75 \\
\hline \multirow{2}{*}{ L.S.D. (0.05) } & -- & 0.01 & NS & 1.47 \\
\hline
\end{tabular}

Table 3: Interactive effect of plant spacing and planting methods on plant height (cm) of Celosia argentea.

\begin{tabular}{|c|c|c|c|}
\hline Treatments & 3WAP & 5WAP & 7WAP \\
\hline \multicolumn{3}{|c|}{ Planting method } \\
\hline Flat & 14.32 & 19 & 27.62 \\
\hline Raise bed & 17.15 & 20.44 & 28.91 \\
\hline Ridge & 15.85 & 22.75 & 31.09 \\
\hline L.S.D. & 0.7 & NS & NS \\
\hline & Spacing & & \\
\hline $15 \mathrm{~cm} \times 30 \mathrm{~cm}$ & 14.58 & 19.11 & 28.98 \\
\hline $30 \mathrm{~cm} \times 30 \mathrm{~cm}$ & 15.88 & 18.92 & 28.46 \\
\hline $45 \mathrm{~cm} \times 30 \mathrm{~cm}$ & 15.45 & 21.22 & 31.42 \\
\hline $60 \mathrm{~cm} \times 30 \mathrm{~cm}$ & 17.22 & 23.67 & 27.95 \\
\hline L.S.D & 0.81 & NS & NS \\
\hline
\end{tabular}

Table 4: Main effect of plant spacing and planting methods on number of leaves of Celosia argentea. 


\begin{tabular}{|c|c|c|c|c|}
\hline Planting Method & Spacing & 3WAP & 5WAP & 7WAP \\
\hline \multirow{4}{*}{ Flat } & $15 \mathrm{~cm} \times 30 \mathrm{~cm}$ & 14.75 & 19.67 & 33.07 \\
\cline { 2 - 5 } & $30 \mathrm{~cm} \times 30 \mathrm{~cm}$ & 14 & 16 & 19.9 \\
\cline { 2 - 5 } & $45 \mathrm{~cm} \times 30 \mathrm{~cm}$ & 16 & 21.67 & 31.4 \\
\cline { 2 - 5 } & $60 \mathrm{~cm} \times 30 \mathrm{~cm}$ & 12.67 & 18.67 & 26.1 \\
\hline \multirow{4}{*}{ Raise bed } & $15 \mathrm{~cm} \times 30 \mathrm{~cm}$ & 14 & 20 & 29.18 \\
\cline { 2 - 5 } & $30 \mathrm{~cm} \times 30 \mathrm{~cm}$ & 20.25 & 21.75 & 39.98 \\
\cline { 2 - 5 } & $45 \mathrm{~cm} \times 30 \mathrm{~cm}$ & 17.34 & 19 & 22.38 \\
\cline { 2 - 5 } & $60 \mathrm{~cm} \times 30 \mathrm{~cm}$ & 17 & 21 & 24.08 \\
\hline \multirow{3}{*}{ Ridge } & $15 \mathrm{~cm} \times 30 \mathrm{~cm}$ & 15 & 17.67 & 24.68 \\
\cline { 2 - 5 } & $30 \mathrm{~cm} \times 30 \mathrm{~cm}$ & 13.4 & 19 & 25.5 \\
\hline & $45 \mathrm{~cm} \times 30 \mathrm{~cm}$ & 13 & 23 & 40.48 \\
\cline { 2 - 5 } & $60 \mathrm{~cm} \times 30 \mathrm{~cm}$ & 22 & 31.33 & 33.68 \\
\hline \multirow{2}{*}{ L.S.D. (0.05) } & & 1.4 & NS & NS \\
\hline
\end{tabular}

Table 5: Interactive effect of plant spacing and planting methods on number of leaves of Celosia argentea.

\begin{tabular}{|c|c|c|c|}
\hline Treatments & 3WAP (cm) & 5WAP (cm) & 7WAP (cm) \\
\hline \multicolumn{4}{|c|}{ Planting method } \\
\hline Flat & 2.54 & 2.73 & 3.49 \\
\hline Raise bed & 2.72 & 3.26 & 4.45 \\
\hline Ridge & 2.4 & 3.19 & 3.87 \\
\hline L.S.D. & 0.25 & 0.24 & 0.04 \\
\hline \multicolumn{4}{|c|}{ Spacing } \\
\hline $15 \mathrm{~cm} \times 30 \mathrm{~cm}$ & 2.55 & 2.94 & 3.52 \\
\hline $30 \mathrm{~cm} \times 30 \mathrm{~cm}$ & 2.43 & 2.93 & 4.17 \\
\hline $45 \mathrm{~cm} \times 30 \mathrm{~cm}$ & 2.5 & 3.19 & 4 \\
\hline $60 \mathrm{~cm} \times 30 \mathrm{~cm}$ & 2.74 & 3.2 & 4.05 \\
\hline L.S.D. & 0.29 & 0.29 & 0.05 \\
\hline
\end{tabular}

Table 6: Main effect of plant spacing and planting methods on Stem diameter $(\mathrm{cm})$ of Celosia argentea.

\begin{tabular}{|c|c|c|c|c|}
\hline Planting Method & Spacing (cm) & $\begin{array}{c}\text { 3WAP } \\
\text { (cm) }\end{array}$ & $\begin{array}{c}\text { 5WAP } \\
\text { (cm) }\end{array}$ & $\begin{array}{c}\text { 7WAP } \\
\text { (cm) }\end{array}$ \\
\hline \multirow{4}{*}{ Flat } & $15 \mathrm{~cm} \times 30 \mathrm{~cm}$ & 3.07 & 3.2 & 3.68 \\
\cline { 2 - 5 } & $30 \mathrm{~cm} \times 30 \mathrm{~cm}$ & 2.07 & 2.1 & 3.08 \\
\cline { 2 - 5 } & $45 \mathrm{~cm} \times 30 \mathrm{~cm}$ & 2.7 & 2.83 & 3.48 \\
\cline { 2 - 5 } Raise bed & $60 \mathrm{~cm} \times 30 \mathrm{~cm}$ & 2.3 & 2.8 & 3.7 \\
\hline \multirow{5}{*}{ Ridge } & $15 \mathrm{~cm} \times 30 \mathrm{~cm}$ & 2.5 & 2.93 & 3.45 \\
\cline { 2 - 5 } & $30 \mathrm{~cm} \times 30 \mathrm{~cm}$ & 3.05 & 3.95 & 5.7 \\
\cline { 2 - 5 } & $45 \mathrm{~cm} \times 30 \mathrm{~cm}$ & 2.6 & 3.27 & 4.68 \\
\hline \multirow{3}{*}{ L.S.D. (0.05) } & $60 \mathrm{~cm} \times 30 \mathrm{~cm}$ & 2.73 & 2.9 & 3.98 \\
\hline & $15 \mathrm{~cm} \times 30 \mathrm{~cm}$ & 2.07 & 2.7 & 3.43 \\
\hline & $30 \mathrm{~cm} \times 30 \mathrm{~cm}$ & 2.17 & 2.73 & 3.73 \\
\hline & $45 \mathrm{~cm} \times 30 \mathrm{~cm}$ & 2.17 & 3.47 & 3.85 \\
\hline & $60 \mathrm{~cm} \times 30 \mathrm{~cm}$ & 3.2 & 3.87 & 4.48 \\
\hline
\end{tabular}

Table 7: Interactive effect of plant spacing and planting methods on Stem diameter $(\mathrm{cm})$ of Celosia argentea moisture and nutrients, thereby causing stem elongation. This was in accordance with Akinfasoye et al., who reported similar result while working on different spacing on growth and yield of Celosia. The tillage methods had a significant $(\mathrm{p}<0.05)$ effect on the herbage yield of Celosia. The highest herbage yield of $3.43 \mathrm{t} / \mathrm{ha}$ was observed at the raised bed while least herbage yield of $3.00 \mathrm{t} / \mathrm{ha}$ was gotten at the flatbed. Plant spacing had a significant $(\mathrm{p}<0.05)$ effect on the herbage yield of Celosia. The highest herbage yield of $4.07 \mathrm{t} / \mathrm{ha}$ was recorded at $45 \times 30 \mathrm{~cm}$ spacing while the least herbage yield of $2.30 \mathrm{t} / \mathrm{ha}$ was observed at $60 \times 30 \mathrm{~cm}$ spacing. The plant spacing with tillage method had a significant influence on the herbage yield of Celosia. The highest herbage yield of $6.50 \mathrm{t} / \mathrm{ha}$ was recorded from $30 \times 30 \mathrm{~cm}$ spacing with raised bed while the lowest herbage yield of $1.00 \mathrm{t} / \mathrm{ha}$ was recorded at $60 \times 30 \mathrm{~cm}$ spacing with raised bed. The significant influence of plant spacing on herbage yield revealed that plant spacing plays a vital role in the production of Celosia (Tables 8 and 9).

As reported by Alam et al., [14] that successful cultivation of any crop depends on several factors of tillage method. The maximum number of leaves and herbage yield of Celosia were obtained at 45 $\times 30 \mathrm{~cm}$ spacing. The result was closely related to Larson [15] who recommended $30 \times 30 \mathrm{~cm}$ for zinna in a field experiment. The higher plant height, stem girth and yield obtained at the raised bed may be due to the soil which is well loss and not compacted in the raised bed and also the roots have good penetration for growth [16]. The raised bed is considered as best planting medium for vegetable production [17].

\begin{tabular}{|c|c|}
\hline \multicolumn{1}{|c|}{ Preatments } & Yield (t/ha) \\
\hline Flat & 3 \\
\hline Raise bed & 3.43 \\
\hline Ridge & 3.22 \\
\hline L.S.D. & 0.26 \\
\hline \multicolumn{2}{|c|}{ Spacing } \\
\hline $30 \mathrm{~cm} \times 30 \mathrm{~cm} \quad$ \\
\hline $45 \mathrm{~cm} \times 30 \mathrm{~cm} \quad 3.27$ \\
\hline $60 \mathrm{~cm} \times 30 \mathrm{~cm}$ & 3.23 \\
\hline L.S.D. & 4.07 \\
\hline
\end{tabular}

Table 8: Main effect of plant spacing and planting methods on Yield ( $t / h a)$ of Celosia argentea.

\begin{tabular}{|c|c|c|}
\hline Planting Method & Spacing (cm) & Yield (t/ha) \\
\hline \multirow{3}{*}{ Flat } & $15 \mathrm{~cm} \times 30 \mathrm{~cm}$ & 5.5 \\
\hline \multirow{4}{*}{ Raise bed } & $30 \mathrm{~cm} \times 30 \mathrm{~cm}$ & 1.1 \\
\cline { 2 - 3 } & $45 \mathrm{~cm} \times 30 \mathrm{~cm}$ & 4.1 \\
\cline { 2 - 3 } & $60 \mathrm{~cm} \times 30 \mathrm{~cm}$ & 1.4 \\
\hline \multirow{3}{*}{ Ridge } & $15 \mathrm{~cm} \times 30 \mathrm{~cm}$ & 2.3 \\
\hline & $30 \mathrm{~cm} \times 30 \mathrm{~cm}$ & 6.5 \\
\hline & $45 \mathrm{~cm} \times 30 \mathrm{~cm}$ & 3.9 \\
\hline & $60 \mathrm{~cm} \times 30 \mathrm{~cm}$ & 2 \\
\hline & $15 \mathrm{~cm} \times 30 \mathrm{~cm}$ & 2.2 \\
\hline & $30 \mathrm{~cm} \times 30 \mathrm{~cm}$ & 4.2 \\
\hline \multirow{2}{*}{ L.S.D. (0.05) } & $45 \mathrm{~cm} \times 30 \mathrm{~cm}$ & 4.5 \\
\hline
\end{tabular}

Table 9: Interactive effect of plant spacing and planting methods on Yield ( $t / h a)$ of Celosia argentea 


\section{Conclusion and Recommendations}

Generally, raised beds produce a variety of benefits, they extend the planting season and they reduce weeds if designed and planted properly [16]. The result of the experiment revealed that the plants with raised bed at spacing of $30 \mathrm{~cm} \times 30 \mathrm{~cm}$ gave the highest response in terms of average growth parameters that were considered at 7 WAP and the yield value after harvesting at $8^{\text {th }}$ week, except that highest number of leaves was obtained at ridge with spacing of $45 \mathrm{~cm} \times 30 \mathrm{~cm}$. It is recommended that raised bed enhance the growth and yield of Celosia therefore farmer should cultivate the habit of using it. And also, sowing Celosia at a spacing of $30 \mathrm{~cm} \times 30 \mathrm{~cm}$ will produce higher yield and there will be no competition among the plant i.e., enough nutrient and moisture will be available in the soil for their growth and yield.

\section{References}

1. Tindall HD (1983) Solanaceae in vegetable in the tropics (1st edn), Macmillan press limited, London, UK. pp: 347-358.

2. Law-Ogbomo, Peter AE (2011) Growth and herbage yield of Celosia argentea as influenced by plant density and NPK fertilization in graded Ultisol. Trop Subtrop Agroecosyst 14: 251-260

3. Chweya JA, Eyzaguirre PB (1999) The biodiversity of traditional leafy vegetables in Rome: International Plant Genetic Resources Institute. Exp Agr p: 37.

4. Brenan JP (1981) The genus Amaranthus in Southern Africa. J S Afr bot 47: 451-492.

5. Grubben JH, Denton OA (2004) Plant resources of tropical Africa 2.Vegetables. Kew. Bull 59: 650 .

6. Fawusi MOA, Ormrod DP (1981) Response to temperature of Celosia agentea.
Sci Hort 15: 215-221.

7. Kusnarta IG, Tisdall I, Mahrup S, Mashum M, Gill JS, et al. (2006) Rice root distribution under various systems of soil management on rainfed vertisols in Southern Lombok, Eastern Indonesia, International Crop Science Congress Proceedings, Australia.

8. Hadas A (1977) Tillage-soil physical conditions and crops responses. International Symposium on Rainfed Agriculture in Semi-Arid Regions. Proceedings, IEEE Xplore, London, UK

9. Goldsworthy PR, Fisher NM (1984) The Physiology of Tropical Field Crops. Exp Agr 21:409.

10. Hulugale NR, Palada ML, Carsky R (1991) Effect of seedbed preparation method. Soil properties and crop yield in rice fallow of South Western Nigeria. Research Organisation Proceedings, IEEE Xplore, London.

11. Noah SG (1997) Effect of seedbed conditions, planting rain and seed vigour on establishments of maize. Sokoine University of Agriculture, Morogoro, Tanzania

12. Tijani EH (2002) Influence of seedbed type and crop density on the yield performance of Celosia argentea (I). Nig J Hort Sci 6:30-35.

13. Dixon HG, Alani RO, Oladunjoye MT (2015) Evaluation of persistence organic pollutants in vegetables around Ogun River at Kara abattoir. Horticultural society of Nigeria Proceedings, Yobe State, Nigeria.

14. Alam MS, Saha SR, Alam MS, Alam MK (2011) Effect of sowing time and planting spacing on the yield and yield attributes of sweet pepper (Capsicum annum). Ban J Agr Res .36: 271-278.

15. Larson RA (1980) Introduction to Floriculture.Department of Horticultural Science, North Carolina State University. North Carolina Academic press NewYork.

16. Raymond N (2010) Raised-bed vegetable gardening made simple (2nd edn), Countryman Press, Vermont, United States.

17. https://www.manta.com/c/mm03wft/roberts-sand-company-III. 